\title{
LEPANTHES MIRACULUM (ORCHIDACEAE), A NEW ADDITION TO THE PERUVIAN ORCHID FLORA
}

\author{
Benjamin Collantes ${ }^{1}$, Julio G. Ochoa ${ }^{2},{\text { Carlos } \text { Martel }^{3} \& \text { Lisa Thoerle }}^{4}$ \\ ${ }^{1}$ Inkaterra-Inka Terra Association, Andalucía 174, Lima 18, Peru \\ ${ }^{2}$ Parque Arqueológico Nacional de Machupicchu, Dirección Regional de Cultura - Cusco, \\ Ministerio de Cultura, Cusco, Peru \\ ${ }^{3}$ Institute of Evolutionary Ecology and Conservation Genomics, University of Ulm, Helmholtzstraße 10-1 \\ Containerstadt, D-89081 Ulm, Germany \\ ${ }^{4} 23$ John Dyer Road, Little Compton RI 02837, U.S.A.

\begin{abstract}
Lepanthes miraculum, formerly known from one area in Bolivia, is reported from Machu Picchu in southern Peru. Illustrations, figures, notes on the specimens found in Peru and an updated description are provided and compared to those known from Bolivia.
\end{abstract}

Resumen. Lepanthes miraculum, conocido de una localidad en Bolivia, es reportado en Machu Picchu al Sur del Perú. Se incluyen ilustraciones, figuras y notas sobre los especímenes encontrados en Perú y se les compara con los conocidos de Bolivia.

Key words: New record, Lepanthes species, Pleurothallidinae, Epidendreae, Epidendroideae, Peru

Introduction. The genus Lepanthes $\mathrm{Sw}$. comprises more than 800 species (Luer 1996, Farfán et al. 2003) and is one of the largest orchid genera. Species of Lepanthes occur from southern Mexico through the Antilles to Bolivia and Brazil (Luer \& Thoerle 2010) and from 100 up to 3300 m elevation (PérezEscobar et al. 2013). In Peru, the number of reported Lepanthes species has increased dramatically during recent decades: 14 species of Lepanthes were recorded by Schweinfurth $(1958,1970)$, but later increased to 46 species as reported by Brako \& Zarucchi (1993) and Ulloa Ulloa et al. (2004). At this moment, the Kew World Orchid Checklist (Govaerts et al. 2015) and Tropicos (www.tropicos.org) record 55 and 63 Lepanthes species for Peru, respectively. This number, however, would be a low estimation of the actual diversity in the country, since there is not yet any study of the genus in Peru. The monumental work of Carlyle A. Luer is mainly based on Ecuadorian and Colombian specimens; thus, in Ecuador and Colombia there are recorded more than 300 species each (Farfán et al. 2003, Thoerle \& Hirtz 2015). If the number of the known species decline at the limits of Lepanthes distribution (Thoerle \& Hirtz 2015), Peru may eventually present more species than Bolivia; however, the last revision of Bolivian Lepanthes recorded 67 species (Luer \&Thoerle 2010). New species and records are expected to significantly increase the diversity of Peruvian Lepanthes as exploration continues.

During explorations in the Machu Picchu Historical Sanctuary (Cusco, southern Peru), the Inka Terra Association team discovered plants of a Lepanthes species with flowers unusual in their size and morphology, later determined to be Lepanthes miraculum Luer \& R. Vásquez. This species was only known from a few collections in the province of Chapare (Cochabamba, Bolivia), and no further details have been given about this species since its publication (Luer 1983). Here, we report L. miraculum as a new addition to the orchid flora of Peru and provide details of the new population, including an updated description and distribution map, and a line drawing and in situ photographs based on the Peruvian specimens.

Material and Methods. Field work in Machu Picchu was conducted in April 2013. The specimen of Lepanthes miraculum was collected and preserved in 


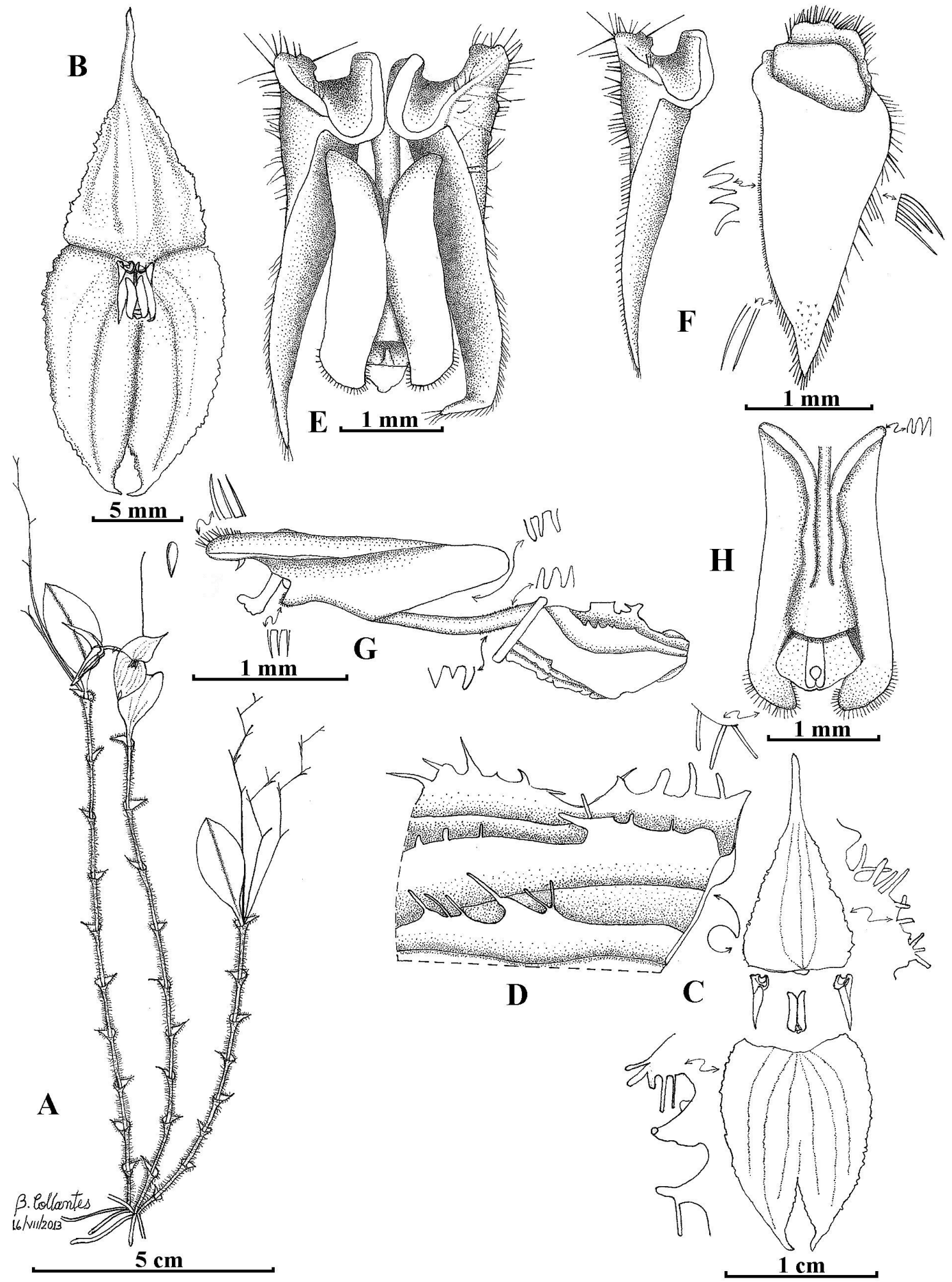


spirits. Micromorphological characters were studied under stereomicroscope. Herbarium specimens from USM and SEL were examined (acronyms follow the Index Herbariorum). The software DIVA-GIS (Version 7.5) and Irfanview (Version 4.33, Irfan Skiljan) were used to prepare the distribution map.

\section{Taxonomic treatment}

Lepanthes miraculum Luer \& R. Vásquez. Phytologia 54: 353. 1983. (Figs. 1, 2).

TYPE: Bolivia. Cochabamba, Prov. of Chapare, epiphytic in cloud forest between Cochabamba and Villa Tunari, elev. 2500 m, 22 Jan. 1980, C. Luer, J. Luer \& R. Vásquez 4906 (holotype: SEL!).

Epiphytic herb. Plant medium in size for the genus, $13-21 \mathrm{~cm}$ tall including the inflorescence, caespitose. Roots fuchsia, relatively coarse, $0.52-0.85$ $\mathrm{mm}$ diameter. Ramicauls slender, erect to suberect, $3.0-11.0 \mathrm{~cm}$ long, enclosed by $6-11$ ciliate or densely pubescent lepanthiform sheaths with ciliate, markedly dilated ostia. Leaf dark green to grayish green, suffused with purple or shiny green beneath, erect, coriaceous, elliptical, subacute, $2.0-3.0 \times 0.9-1.2 \mathrm{~cm}$, the base cuneate into a petiole $2.0-5.0 \mathrm{~mm}$ long. Inflorescence 1-3 fractiflex, successively flowered racemes bearing 2-13 flowers, borne above the leaf, up to $11 \mathrm{~cm}$ long including the slender, terete peduncle $2.5-4.0 \mathrm{~cm}$ long; floral bracts 1.5-2.0 mm long, ciliate; pedicels 2.5-4.0 $\mathrm{mm}$ long; ovary 6-winged, wings irregularly erosedentate, 1.5-2.0 mm long. Flowers color of sepals dark brownish orange to dark red, veins brownish, margins orange; petals orange with golden yellow apices and anterior margins, or red; the lip dark, dull pink or bright purple; the column rose-purple; sepals spreading, noticeably papillose to shortly pubescent internally, externally carinate along the veins, carinae with irregularly erose-dentate margins with digitiform projections; dorsal sepal with margins erose-dentate with digitiform projections, triangular-ovate, the apex acuminate into a cauda $c a .5 \mathrm{~mm}$ long, 10.5$14.0 \times 6.5-7.0 \mathrm{~mm}$ including the cauda, 3-veined; synsepalum with margins erose-dentate with conic apices, some with filiform projections, broadly ovate, basally concave, $11.5-14.0 \times 8.5-10.0 \mathrm{~mm}$ including the caudae, with the distal third $(c a .4 \mathrm{~mm})$ free, the apices acuminate into short caudae, 6-veined; petals transversely bilobed, the upper lobe reflexed, asymmetrically subcordate expanded, with short and long cilia, $1 \mathrm{~mm}$ in diameter expanded; the lower lobe narrowly triangular with cilia longer at the base, shorter toward the apex, $3.0-3.5 \times 1.0 \mathrm{~mm}$; lip bilaminate, the blades oblong-subsigmoid, 1.75-2.0 mm long, glabrous except for short cilia at the narrowly obtuse, inverted apices, the bases rounded, everted, with conicdigitiform papillae, the connectives broadly cuneate, connate to the column near the middle, the sinus obtuse with a broad, membranous, retuse, ciliate appendix in contact with a foot-shaped, clavate appendage from the stigma; column 2.0-3.0 $\mathrm{mm}$ long, the apical half dilated, the shaft microscopically papillose, terete, extremely slender; anther dorsal, stigma ventral; pollinia not observed.

Additional specimens. Peru. Cusco: Prov. Urubamba, Distr. Machu Picchu, Santuario Histórico de Machu Picchu; Pampaccahua, km 90 de la vía férrea CuscoMachu Picchu, Sector El Palomar [bosque anexo a las inmediaciones del nevado Huaqayhuillca], elev. ca. $3,000 \mathrm{~m}$, B. Collantes, J. Ochoa \& C. Soto 178, $12 \mathrm{Apr}$. 2011 (USM!). Bolivia. Cochabamba: Prov. of Chapare, epiphytic in cloud forest between Cochabamba and Villa Tunari, elev. 2,600 m, 26 Nov. 1978, C. Luer 3490 (SEL); same area, collected by B. Wuerstle, elev. 2,700 m, 13 Jan. 1981, C. Luer 5662 (SEL); Pampa Tambo [in the department of Cochabamba, not Potosí], elev. 2,800 m, 24 Dec. 1979, R. Vásquez 234 (SEL).

Etymology: From the Latin miraculum, "a marvel," referring to the features of the flower.

Distribution And Ecology. The species is known from two disjunct areas (Fig. 3). The earlier collections are from the Province of Chapare (central Bolivia) and the newest is from the high mountains of the Machu Picchu Sanctuary (southern Peru). Plants of Lepanthes

Left: Figure 1. Lepanthes miraculum. A. Habit. B. Flower, frontal view. C. Dissected flower with details of the sepaline margins. D. Detail of a carina from the exterior of the dorsal sepal. E. Petals, lip, and column, frontal view. F. Right petal, frontal and lateral views. G. Ovary, lip, and column, with surface details, lateral view. H. Lip and column, ventral view. Drawn from B. Collantes et al. 178 (USM) by B. Collantes. 


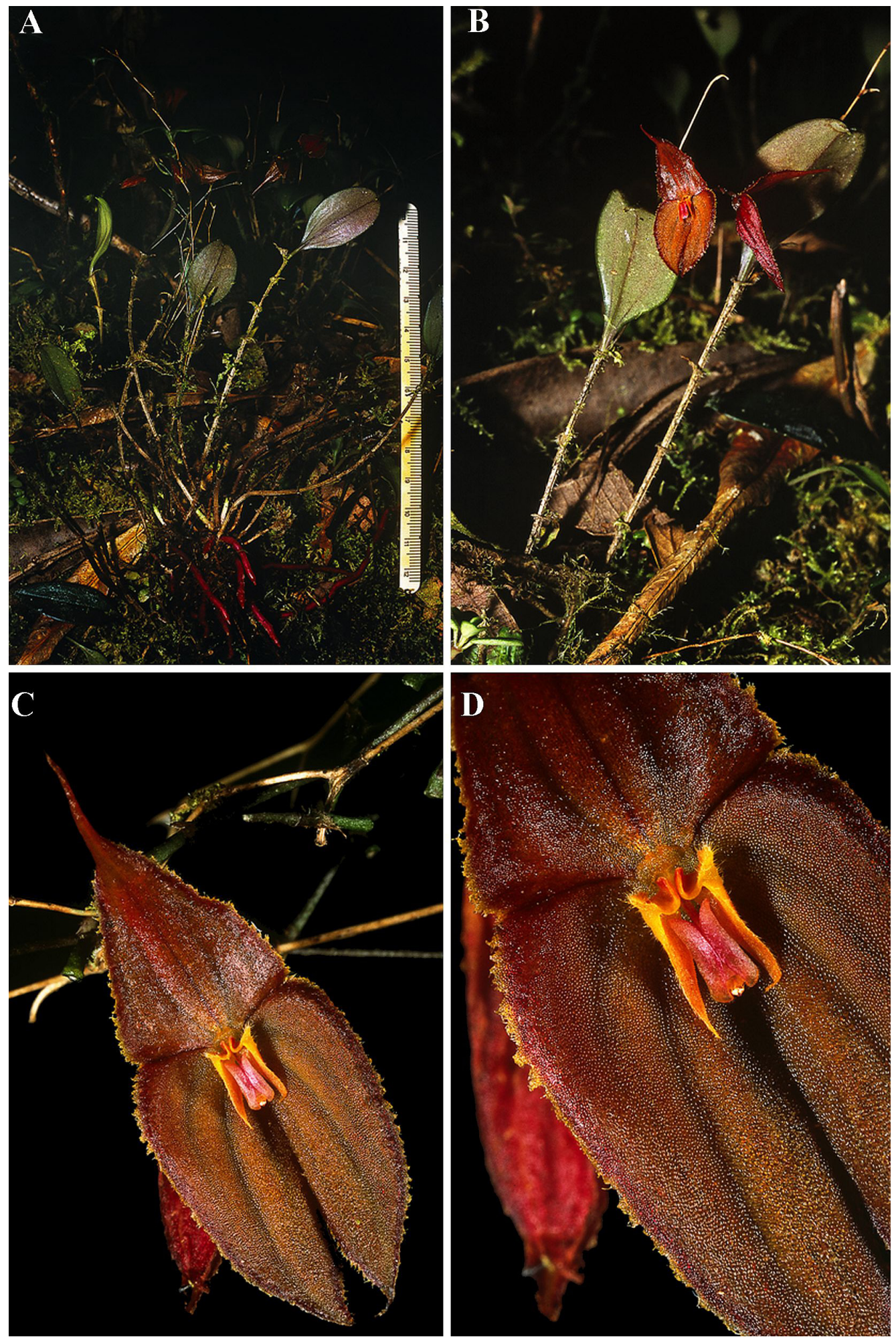


miraculum occur in cloud forests at elevations from 2500 to $3000 \mathrm{~m}$. The present report extends its distribution by $c a .800$ linear $\mathrm{km}$ northward. Chapare and Machu Picchu cloud forests may formerly have been linked since another orchid species, Vasqueziella boliviana Dodson, which also has a very restricted distribution, was recorded to be present only in the same two areas (Jenny 2011). In Peru, plants of $L$. miraculum were observed growing on exposed trunks and branches of Polylepys pauta Hieron. (Rosaceae), which is the dominant tree species in the newly recorded habitat. An additional population was found inside the Machu Picchu Historical Sanctuary, on Cerro Poques, by the Inkaterra Association team (C. Soto 2013, pers. comm.).

Phenology. The population found in Peru flowers from March to April, whereas the collections from Bolivia have been recorded to bloom from November to January.

Conservation status. This species is presently known from only two places. The populations occurring in Bolivia are especially endangered and the species may even be extinct (Vásquez et al. 2003). The populations found in Peru occur inside a protected area (the Machu Picchu Historical Sanctuary); nevertheless, anthropic activities may imperil its small populations. According to the IUCN Red List (IUCN 2014), it can be listed as critically endangered (CR, criterion B1/extent of occurrence and $\mathrm{C} 1 /$ small population size and decline).

Lepanthes miraculum belongs to the section Lepanthes subsection Lepanthes (Luer \& Thoerle 2010). The flowers are large for the genus, but most unusual are the folded petals and the long, thin column with the broad connectives of the lip connate at about the middle. The specimens found in Peru present a ramicaul enclosed in densely pubescent lepanthiform sheaths similar to those of L. pubicaulis C. Schweinf, rather than less densely ciliate like those of the Bolivian specimens. The flowers from the two areas also vary, those from Peru having a flower with larger sepals (14 mm long vs. 10.5-11.0 mm long in the Bolivian specimens) that are minutely but visibly papillose internally, rather than shortly pubescent. The color of

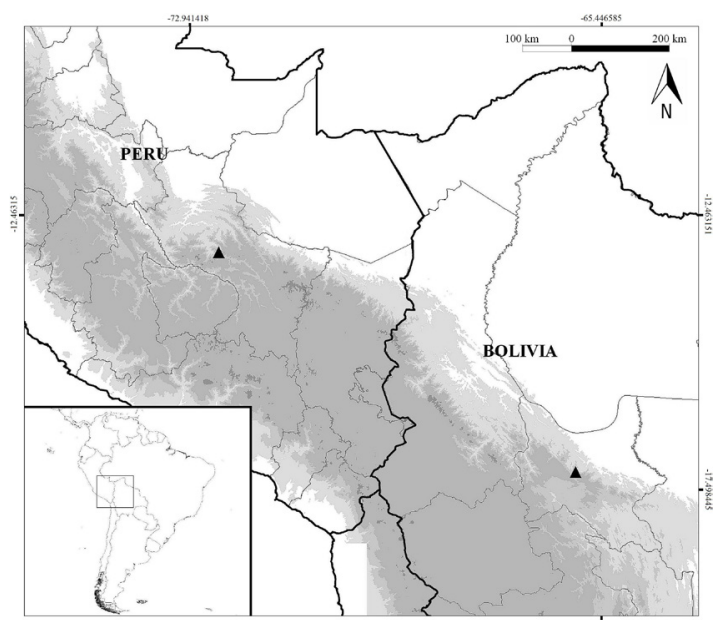

FIgURE 3. Geographical locations of Lepanthes miraculum (triangles) in Peru and Bolivia. Gray scale indicates elevation (white $[0 \mathrm{~m}]$ to dark gray $[6,500 \mathrm{~m}]$ ). Produced by Carlos Martel.

the flowers differs: sepals of the Peruvian individuals are brownish orange to dark red, the petals orange and golden yellow, whereas the Bolivian ones are red to dark red, and red, respectively.

ACKNOWLEDGEMENTS. We kindly thank the Inkaterra team at Machu Picchu for the logistic support; the Jefatura del Santuario Histórico de Machupicchu of the Servicio Nacional de Áreas Naturales Protegidas (SERNANP) of Peru for issuing the collection permit under which orchid specimens have been collected ( $\mathrm{N}^{\circ}$ 009-2010-SERNANPSHM-J); Carmen Soto for sharing information about an additional population; and the staff at SEL for their hospitality and access to the collections.

\section{LiteRATURE CITED}

Brako, L., \& Zarucchi, J. L. (1993). Catalogue of the flowering plants and Gymnosperms of Peru. Monographs in Systematic Botany from the Missouri Botanical Garden, 45, 1-1286.

Farfán, J., Tupac Otero, J. \& Luer, C. A. (2003). Lepanthes (Orchidaceae) species of Colombia. Biota Colombiana, 4, 33-47. Available from: http://www.redalyc.org/ pdf/491/49140102.pdf. Accessed 22-09-2015.

Govaerts, R., Bernet, P., Kratochvil, K., Gerlach, G., Carr, G., Alrich, P., Pridgeon, A. M., Pfahl, J., Campacci, M. A., Holland Baptista, D., Tigges, H., Shaw, J., Cribb,

Left: Figure 2. Lepanthes miraculum in situ. A. Habit. B. Plant with inflorescences. C. Flower, frontal view. D. Closeup of the flower. Photographs by B. Collantes. 
P., George, A., Kreuz, K. \& Wood, J. (2015). World checklist of Orchidaceae. Facilitated by the Royal Botanic Gardens, Kew. Available from: http://apps.kew. org/wcsp/. Accessed 01-09-2015.

IUCN. (2014). Guidelines for using the IUCN Red List categories and criteria. Version 11. Prepared by the Standards and Petitions Subcommittee in February 2014. Available from: http://www.iucnredlist.org/documents/ RedListGuidelines.pdf. Accessed 21-05-2015.

Jenny, R. (2011). Vasqueziella, an unknown genus. Orchid digest, 75, 84-86.

Luer, C. A. (1983). New species of Lepanthes (Orchidaceae). Phytologia, 54, 325-378. Available from: http://www. biodiversitylibrary.org/item/46790. Accessed 30-32016.

Luer, C. A. (1996). Icones Pleurothallidinarum XIV: The genus Lepanthes, subgenus Lepanthes in Ecuador. Monographs in systematic botany from the Missouri Botanical Garden, 61, 1-255.

Luer, C. A. \& Thoerle, L. (2010). Icones Pleurothallidinarum XXXI: Lepanthes of Bolivia. Monographs in systematic botany from the Missouri Botanical Garden, 120, 1-64. Pérez-Escobar, O. A., Kolanowska, M. \& RincónUseche, C. (2013). A new species of Lepanthes
(Pleurothallidinae, Orchidaceae) from Colombia. Systematic botany, 38, 316-319. doi: http://dx.doi. org $/ 10.1600 / 036364413 \times 666822$

Schweinfurth, C. (1958). Orchids of Peru. Fieldiana Botany, 30, 248-260. Available from: http://www. biodiversitylibrary.org/item/19974. Accessed 30-32016.

Schweinfurth, C (1970). First Supplement to the orchids of Peru. Fieldiana Botany, 33, 1-80. Available from: http:// www.biodiversitylibrary.org/item/20445. Accessed 303-2016.

Thoerle, L. \& Hirtz, A. C. (2015). Three new Lepanthes species (Pleurothallidinae, Orchidaceae) from Ecuador. Phytotaxa, 201, 50-62. doi: http://dx.doi.org/10.11646/ phytotaxa.201.1.3

Ulloa Ulloa, C., Zarucchi, J. L. \& León, B. (2004). Diez años de adiciones a la Flora del Perú: 1993-2003. Arnaldoa, Edic. Esp. Noviembre 2004, 1-242. Available from: http://www.biodiversitylibrary.org/item/129229. Accessed 30-3-2016.

Vásquez, R., Ibisch, P. L. \& Gerkmann, B. (2003). Diversity of Bolivian Orchidaceae - a challenge for taxonomic, floristic and conservation research. Organisms diversity \& evolution, 3, 93-102. doi: 10.1078/1439-6092-00061 